\title{
Making Films in a Brazilian's Slum with Children: a Participant Observation Research
}

\author{
Raquel Pacheco \\ CIAC \\ Universidade do Algarve, Portugal \\ raquel.pacheco@gmail.com
}

\author{
Mirna Juliana \\ Universidade Católica de Petrópolis / \\ Grupem - PUC-Rio \\ Brasil \\ mirnajuliana@gmail.com
}

\begin{abstract}
This article stands for innovative learning opportunities to social inclusion by film education. The theoretical model is a combined structure coming from approaches and projects of social inclusion through film education. The aim is to describe and analyze the film education process in a project outside the school. This research is based on a participant observation research conducted on children in a Brazilian slum. Cinema, as other art forms, is a political and ideological tool that can be used with different purposes. Film education is a strong mediator to facilitate transformative learning, changing one's dysfunctional views and beliefs about oneself and the world by revising their frames of reference (Mezirow \& Taylor, 2009). Films have a unique ability to promote empathy towards a role model, and promote resilience in situations similar to those the role model goes through. Furthermore, media, such as films, is capable of reaching people that might otherwise be uninterested (Buckingham, 2007; Gonnet, 2007; Silverstone, 2005; UNESCO, 2013).
\end{abstract}

\section{KEYWORDS}

Film Education; Cinema; Children; Pedagogy; Ethnographic Research.

\section{1 | INTRODUCTION}

In Brazil, individual teacher initiatives associated with governmental and non-governmental organizations promoting screening activities and film discussion for students and teachers from the elementary and secondary school network are helping to build a movie appreciation culture in educational institutions (Duarte, 2002).

Even though it's valued, cinema is not yet seen by educational media as a source of knowledge. We know that art is knowledge, but we have trouble recognizing cinema as art (with a variable quality production, like all other forms of art) (Duarte, 2002), because we are imbued with the idea that cinema is fun and entertaining, especially when compared to the arts considered the noblest.

Film education, which falls within the range of media education, promotes film and audiovisual literacy, as it contributes to the construction of media literacy. This study intends to deepen the knowledge of children with disadvantageous backgrounds about cinema and audiovisual cultures. The goal is to understand the filmic and audiovisual capacities they develop, to identify those in need of intervention and the most effective ways of doing so. Particular attention is to be paid to the work of film education and audiovisual literacy, given the role these play among the younger generations with new media and technological developments.

Throughout this project, the field of film education was researched, taking into account the Brazilian reality, in an effort to systematize, clarify, identify and 
understand the core elements of the fields of cinema and education and the relation among them. For that purpose, we developed a participant observation research that lasted four months. The observations took place at the entrance of the Morro dos Prazeres slum (favela) located at the top of the hill of Santa Teresa.

Children who participate in the Casarão film workshop live in an area where, although considered upper middle class, a slum (favela) is located. This slum occupies an entire hill called Morro dos Prazeres. It was one of the communities chosen to receive the implementation of a Pacifying Police Unit (UPP). It is important to mention that the casting out of the drug trade is one of the processes carried out in the new routine of local residents, who now have to live with the police. Boys and girls who participated in this particular workshop are not at school or busy with busy with extra activities concerning the Casarão project, they wander through the alleys of the slum as they have no one at home to look after them and supervise their activities. But, in the project of film education, these boys and girls are considered young protagonists. And in this article we will see what that means.

\section{2 | THEORICAL FRAMEWORK}

Qualitative methodologies, mainly participatory and action research, are starting points for developing an integrated and comprehensive media education project, including film, audiovisual, information, entertainment and advertising in different media.

Media education works at different levels: academic, governmental and through specific initiatives, especially in schools. Despite this scenario and the efforts to institutionalize it through an implementation directive, the commitment to educate citizens on communication and the media has not yet become a public policy goal (Pinto, 2014). The UNESCO expert meeting at the World Summit on Information Society considers media literacy to be the core of the skills in the 21st century (UNESCO 2013). During the 7th Global Media and Information Literacy Week 2017, Media and Information Literacy (MIL) in Critical Times: Re-imagining Ways of Learning and Information Environments, Irina Bokova, then UNESCO's Director-General stressed that "across the world women and men have more access to information than ever before", which opens up "vast new horizons to create and share knowledge" and raises new challenges.

The relevance of MIL lies in how it enables, especially the young, to transform information into knowledge by building more inclusive knowledge societies and promoting dialogue, tolerance and actions promoting human rights. Through specific recommendations and directives, institutions in the EU reinforce the role of media literacy, highlighting the challenges posed by audiovisual and digital media, and the economic demands of the sector.

Academic research ranging from communication and media studies to education studies provides evidence on the benefits of educating younger citizens for contemporary life with the media, and stimulating critical thinking (Buckingham, 2007). These studies and policies combine in an attempt to respond to the consolidation of digital media in the last decade, which open up greater possibilities - if not always activated (Livingstone et al., 2010) - for content creation and participation.

The main philosophy of the British Film Institute Department of Education is to cultivate the idea that, in the same way society has the responsibility of helping a child to read and write, it must also help the child or young person to use, enjoy and understand moving images, not only to be technically capable of watching audiovisual material, but culturally literate. The reality of film education in the UK is based on a work that has been developed within the institutions with government support, for nearly a century. Other and different forms of film education are being developed around the world Fantin (2005) reinforces this argument when she underlines that the relationship between cinema and education has historically been marked by teaching practices in the school context that used film as a mere visual aid. Learning through cinema can often be something merely instrumental, like using films as a supplement of the syllabus (Pereira, 2011).

Cinema's training potential makes it inevitable to be used as this type of feature, "because it is the nature of its insertion in school" (Fantin, 2005: 114). It is in this threshold between the "educated" use that reduces films to another teaching resource and the use of cinema as an object of "aesthetic and expressive experience of sensitivity, knowledge and multiple human languages." (Fantin, 2005: 114). The author believes that we can rethink the dimensions of 
cinema and pedagogies used in work processes within film education.

In the studies conducted by Duarte (2012) about the relationship between children and young people with cinema, it was observed that they are interested in watching many films on TV, the computer and DVD, but rarely go to movie theaters. In general, they enjoy what they are already familiar with and are not to inclined to get in touch with what is beyond the established pattern.

Viewers who have no opportunity to experience films in the most appropriate conditions for enjoying them, tend to transfer into their relationship with cinema, their ways of watching television associated, in general, with the experience of fragmented and intermittent attention. (...) Love for films [...] that leads one not just to watch but also to know and enjoy films, does not evolve on its own. On the contrary, it is built mostly through the mediation of adults who know this artistic value and, thus, understand that it needs to be a part of the new generations' lives. (Duarte, 2012: 3).

Duarte's previous assertion is actually a paradigm, a theoretical goal for most educators and theorists who work in the field of film education. They believe that by exhibiting classic films to children and young people, showing them that these films are a form of art, they can teach them the techniques employed to produce/make films and letting them repeat the process of producing and directing a film.

In 2000, the filmmaker, critic and cinema teacher Alain Bergala was invited by the French Minister of Education, Jack Lang, to develop a plan of public policies whose purpose was to include art and culture in primary education in the France's public schools. This was an ambitious plan called Le Plan de Cinq Ans, joining efforts of the ministries of Education and Culture for the benefit of this goal.

Feeling the need to systematize his more than twenty years of this experience, Alain Bergala published "L'hypothèse-cinéma: petit traité de transmission du cinéma à l'école et ailleurs" (2002), a reflexive book that presents concrete proposals for an introduction to cinema studies at school. His cinema-hypothesis, to put it briefly, recommends that we should never forget that cinema is firstly and foremost an art, a culture in itself, increasingly threatened by amnesia, and a language that, for being so, requires apprenticeship (Bergala, 2002).

In his book, Bergala addresses mainly those who are willing and interested in being what he calls transmitters and/or initiators of the art of cinema. The author emphasizes that the central question is to know how to teach cinema as art in the school context, given that art is a ferment of profound transformation. How to choose the films to be introduced to students? How to expose children and young people to this encounter? Does film education necessarily imply that students should only be able to direct a film? What is film analysis when the aim is creative initiation? These are the kinds of issues raised by Bergala in his cinema-hypothesis, which often tend to guide the thinking of those intending to work (and those who already work) in the field of film education.

It is up to the viewer's pedagogy to go beyond reading the movies and put their knowledge in practice, that is, engage in the act of making the film. This is a magic moment because it is the moment when cinema reinvents and rediscovers itself. Making a film reflects the empowerment of these subjects of action, giving voice and opportunity of expression to those who, hitherto, only read and debated about art work. In the same vein, Clarembeaux (2010) conceives cinema education as an essential element in the digital era and understands, like Bergala, the importance of the proposal as long as it supports a tripod of complementary and associated poles in the activities of: seeing, analyzing and producing movies with young people.

On the practice field, Bergala created the programme "Le cinéma: cent ans de jeunesse" (Cinema: one hundred years of youth) involving school classes ranging from primary school children (about 6 yearsold) to secondary school students (around 17 yearsold), from various regions of France and different social backgrounds. Later the programme was expanded to Guadeloupe and Martinique, and also countries like Portugal, Spain, Italy, UK, Cuba and Brazil.

All these different groups work on a theme related to cinema: point of view; real space/filmed space; mise en scène, etc. To develop the theme chosen for a year's work with students, teachers and film professionals, who assist students in this project, 
receive a DVD containing various portions of significant films on the subject, taken from different genres of films from all over the world. These teachers participate in at least two annual meetings in Paris. "Each teacher or intervener draws from these meetings what seems to be appropriate in relation to the real educational situation they are in." (Bergala, 2008: 82). Bergala assures that the whole process adapts to the reality of each group and each context.

In education, we have to be careful not to guide ourselves by what is believed to already be working well in a perspective of repeating what already seems to be accepted. Exploring new horizons may not be easy, but if it is done with truth and love, it will certainly bring incalculable benefits.

The risk of sharing your own passions and convictions is definitely not part of the teaching profession, highlights Bergala (2008), nor is it a necessary talent to be a good teacher. Meanwhile,

(...) when an adult accepts the voluntary risk of becoming a transmitter - by conviction and personal love for a form of art - he also changes his symbolic status, abandoning his role of teacher for a moment, as defined and delimited by the institution, and returns to the word and the contact with students, from another place within himself, less protected. A place that involves his personal tastes and his most intimate relationship with this or that work of art. The self that might be harmful to the teacher's role becomes virtually indispensable to a good start. (Bergala, 2008: 64).

In this sense, Bergala (2008) believes that the student needs the hands-on experience of making a film and needs to have contact with the artist, the film professional, who is understood as an outsider, the other within the school context. This becomes the positively disturbing element. The author also believes that for young people to have a greater perception of cinema, it takes more than just being in the classroom analyzing films. Whoever believes in that has "a very angelical idea about the balance of power between pedagogical intervention, the media's ideological firepower, and the image and sound environment" (Bergala, 2008: 39).

Neuroscience has long since discovered that there are different areas and levels of pleasure in the human brain (Ascenso, 2012). Bergala (2008) reinforces this idea when he affirms that we all feel a sort of pleasure when, after an exhausting day, sit in front of television to watch any program that does not require us to think, that makes us forget a little about who we are or what we do. But this kind of pleasure is a fleeing, shallow pleasure, according to neuroscientist João Ascenso (2012). It is a pleasure that does not require any effort from the brain. So this habit is not constructive at the same time that it does not cause any damage, as long as we are not limited to use just this respective pleasure area of the brain. "But that does not change the awareness that there are pleasures of different natures, whose economy, intensity and impact do not lie in the same level." (Bergala, 2008: 69).

There is a pleasure that should be built in the brain preferably during childhood, but that should be encouraged and worked throughout life. This is not necessarily an immediate and effortless pleasure and school can and should play an important role in this type of acquisition and/or construction (Bergala, 2008). The construction of more durable and higher forms of pleasure should be encouraged and developed in children, young people and adults, even if it requires a deeper and more elaborate work (Ascenso, 2012).

In our materialistic consumer society we find many different kinds of pleasures for sale. Most of the media disseminators and supporters of this system create and reinforce, all the time, the human need to seek happiness, while selling a hedonistic, ephemeral, foreign, empty and very material happiness. "All that civil society suggests to the majority of children are cultural goods quickly consumed, quickly perishable and socially mandatory", Bergala notes (2008: 32).

The pleasure and happiness that Bergala (2008) and Ascenso (2012) tell us about are acquired through constant work and effort. This should involve the brain and also the heart, i.e., love, which becomes the means and the end to reach deeper brain areas that produce changes.

\section{3 | METHODOLOGY AND RESEARCH}

From Casarão dos Prazeres we have a nearly $360^{\circ}$ view of the city of Rio. Very beautiful to look at, it is kind of a cultural center, very well taken care of Rio de Janeiro. Casarão dos Prazeres offers several 
social projects focused mainly on children and young people from Morro dos Prazeres. It is an Integrated Education Center (CEI) and offers free and open activities and courses for children and young people. Tatiana (a fictitious name, as well as the others, cited here), the film teacher who brought the project to the group, told us that the places where she usually carries out the project and teaches classes are not like that. She said that she had never participated in a project in such a beautiful and well kept place. Tatiana justified it by saying that it should be because Santa Teresa is a very important tourist place for the city.

At Casarão we followed/ observed a Project "Imagens em Movimento" (PIM) - a private programme in charge of implementing film workshops through the "Le cinéma, cent ans de jeunesse" methodology. The work is developed by two teachers with 11 children of about 9 to 13 years of age. There were 8 girls and 3 boys: Geovana, Isabela, Artur ( 9 years-old); Beto, Cassiane, Stephany, Sofia, Alice, Luana (10 yearsold); Raquel (12 years-old); Igor (13 years-old). All of them were in situation of poverty and risk of social exclusion. Most of them had already been studying theater with Aline, a drama teacher, for more than 2 years.

During the months that we carried out the fieldwork and observed the education film workshop lessons, we used the qualitative methodology, more specifically the participant observation. We recorded the weekly meetings in the field diary. We also conducted unstructured interviews with the teachers, the children and some people who participated in the tasks in the place. Some of the children's parents who participated in the workshop were also interviewed.

Aline has taught acting/drama classes at Casarão for more than three years to a group formed, more or less, by the same children. That means that most of them started taking acting classes at the project while they were still 6, 7 and 8 years-old. She teaches acting/ drama classes to this group two afternoons a week, for three years now. They brought to stage a story written by the well-known children and young people's Brazilian writer Ana Maria Machado and acted it out to the author herself during the a book fair. Aline remarks: "Now can you imagine what this means?" And that's not the only play they have acted out. There were other plays authors attended by their authors.
Throughout this time working with the kids, the teacher developed participatory pedagogy which sees the students as whole beings and as citizens. Her working dynamics is to use drama and performing arts, and now cinema, as a means to work different issues of interest to these kids. They have experienced many situations in the acting classes from a very early age, through the work of a horizontal, participatory, humanized and very serious pedagogy that is being developed by the educator for many years. Casarão has turned out to be a unique project. Participants work in a very affectionate environment and a very well kept place that looks out to the whole city. This provides them with a feeling of power and freedom. In addition to that, participants themselves have taken the initiative to study drama. Perhaps all of these factors together may have produced a very well prepared group.

The teacher knows each of the student's life story, their qualities and difficulties and does not use this information as a mechanism for labeling them. On the contrary, she always places herself as an educator, one who allows them to overcome every difficulty and works with them in the acquisition of qualities and understanding themselves and life. In this century's education, Morin (2002: 35) stresses that we need to have more structures to accommodate the new, "and once the unexpected arrives, one must be able to review the theories and ideas instead of forcing the new fact into a theory that is truly unable to host it." It is essential that the human being is seen and treated as a whole, a being who experiments conflicts between impulsivity, heart and mind. The truly human development involves the joint development of individual autonomy, community participation and a sense of belonging to the human species. And the education of the future should ensure that all these concepts and ideals remain alive and that human unity and diversity won't destroy or eliminate each other (Morin, 2002).

It was considering a further enrichment and a broadening of perspectives and knowledge of her students that Aline has decided to sign up her drama workshop group to participate in the PIM film classes. Aline's group was selected and had film classes with Tatiana, the film teacher and PIM coordinator, for a semester, always in the presence of Aline. 
Aline and Tatiana set up the equipment. The children are relaxed. They talk about various things. They talk to each other, while the two teachers look for cables, connections, etc. Tatiana starts the class introducing me, asks me to tell the class about what I do. Tatiana asks a student to distribute some yellow notebooks to the class. (Excerpt Field Diary FD: 4).

The notebooks have "Le cinéma, cent ans de jeunesse" on the cover. They came from France and belong to the project coordinated by Alain Bergala.

Tatiana says that this is the film notebook and that each student will get one.

Isabela: Teacher, does cinema stink?"

The teacher asks why that question and the student answers: "Because this notebook does not smell good..."

Tatiana: "That's musty, because of the humidity. This notebook is for you to write the new things and words you're learning in this cinema workshop". Then she asks each one to pick up a pen to start discussing and writing about what they've learned so far. (FD: 10).

This dialogue shows that the student has never been in a movie theater and associates the smell of the notebook with the smell of the movie theater. Anyway he is having classes to make a film with his colleagues. However when a film is produced, be it long or short, a fiction or a documentary, a depiction of a given person, object or situation, it does not matter how simple or complex the "audiovisual document" produced is, it is done with a purpose, a human intent, using a discourse and a language.

Students who have no pens to write borrow them from the student making pens with colored hair to sell. One student asks the colleague how much she is selling the pens for. She says $R \$ 5.00$, which costs $R \$ 10.00$ in the city, in the peddler. So, the ones she makes are cheaper.

Artur: "God! With $R \$ 5.00$ I can have a party at my school."

Students use the pens made by the girl, but the majority say they're going to use but won't buy one. They are just going to borrow them. The girl doesn't mind.

Tatiana writes on the computer and the text shows up on the screen for students to copy. She writes about what a Zoetrope is, what a plan, cut, frame, viewpoint are, etc., and asks students to define what a plan is as if they were explaining it to their mothers.

Stephany: "My mother doesn't understand it. She will just not understand it."

Alice: "A plan is a cut."

Tatiana: "A cut is a cut, not a plan."

Cassiane: "Geee, this sounds just like the test." (FD: 22).

\section{4 | RESULTS AND ANALYSIS}

For both Freire (2005) and Kaplún (2002), the real communication should not be held by a sender or transmitter who speaks and a receiver who listens, but by two or more human beings or communities who exchange and share experiences, knowledge, feelings by artificial means, even if at a distance. Through this process of exchange, human beings establish relations with each other and pass on experiences from individual isolated existence to community social existence.

Beto (student): "Is it already in viewpoint? I know what it is, it's when I'm inside the camera."

Tatiana laughs and asks: "When are you inside the camera?"

Beto: "It's when the camera shows my vision." (FD: 13).

Communication and education, Kaplún stresses, must serve a transformative educational process, in which the addressed subjects critically understand their reality and acquire tools to transform it. To achieve an authentic communication one should not begin speaking, but listening, because the main condition for a good communicator is the ability to listen and have dialogue and participation as goals (Kaplún, 2002).

Now a Godard film is screened, with subtitles in Portuguese. It takes place during a meal. 
Mother and teenage son are eating and talking. The conversation is not friendly.

Geovana: "Not even I eat like that, with that bowl."

Student says the dialogue is too fast.

Raquel: "He seems to be a spoiled brat."

Tatiana: "Did you count the cuts? Very confusing, right? Reading subtitles, counting cuts ... This film was made by a filmmaker called Godard."

Igor: "It is the same name as Jimmy Neutron's dog from Nickelodeon" (children's cable TV channel).

Tatiana: "What does this scene mean to you?"

Artur: "Loneliness, it's very dark back there. Look at the empty table. Mother and son are not friends."

Luana: "It looks like a horror film".

Tatiana: "It's not horror. It's anguish. They don't have a very good relationship. And what about this plan? She shows another plan. What do you think? What do this and the previous one plans have in common? Both are decentralized. That happens when we take the character from the center of the screen and move it more into the corner. So we have seen three camera positions. This is the third." (FD: 12-13).

However, Sodré (2012: 203) believes the relationship between electronic technology and the educational process takes the risk of repeating the traditional pedagogy: "...only modernizing it technically, if it does not put the historical justification offered by technology for the reinvention of educational forms in the foreground."

Aline says that she posted some black and white pictures from last class on Facebook and that everyone likes them. So she wrote: "Cinema class in the attack, with black and white films by Hitchcock and Godard included. Students asking the teacher for some more black and white films."

Aline adds: "You guys are the best, only in my class! Did you see this on my Facebook page?"
Sofia: “I did teacher. I loved it”. (FD: 14).

Freire (2005) assumes that in order to free a country, first of all, it is necessary to free the consciousness of the people who have been enslaved by antigrassroots ideas and values instilled by their colonizers. The concept of awareness, for example, initially thought of as psychopedagogic, evolves to the understanding of the educational contribution to the pursuit of class consciousness - with the incorporation of Marxist analysis' rules (Scocuglia, 1999).

But what distinguishes Freire from other thinkers who defend liberalism is that he departs from the pure and simple liberalism and values the awareness of the social conditions which account for the educational process. Muniz Sodré highlights that Freire's emphasis is not on the public schools autonomy, for example, but on the student's awareness autonomy "and on school practices tuned with an understanding of knowledge contents" (Sodré, 2012: 129).

Aline says she thinks last class was too theoretical for this group. She says students are very young and she thought it was very demanding for them, expressing a certain fear of students' giving up on the workshop because of that. She shows some concern in relation to last class dynamics. We realize that her main concern is that cinema instructor work is very different from Aline's. Cinema teachers are focused on making these children learn the basic techniques so that they can make films, while the Aline, as an educator, cares for the whole process. Aline is concerned about Tatiana, with this teaching methodology, jeopardizing the work she has been developing with the students for years. And as much as Aline tries to show this to Tatiana, she does not seem see. She is so focused on her reality that she forgets to look at the whole context and observe more closely who those children are, what role the teacher plays and their reality itself. Aline is soft-spoken, simple, humble, acts calmly but is very attentive to students. They are the protagonists for her. The drama teacher has been working with some of these kids for more than three years. She builds on the most beautiful, caring, Freire-like, loving, educational work of all the teachers we saw 
and met during the long course of conducting this research. (FD: 16).

But when the first day of filming arrives all the kids get anxious. A group of girls picks up the camera of the making of and begins to take pictures imitating a scene from the movie Titanic, when the main actress opens her arms when standing on the bow of the ship. The audiovisual references of the students come from the commercial films of Hollywood and the Rede Globo soap operas.

During the filming a new student's father came in, whom Aline had mentioned worked with filming, photography and things of the area. The father talked to his son and Aline. The theater teacher joked about whether her father had come to check the footage, the father smiled and said that he left work early to come and see his son in the workshop. (FD: 20).

\section{5 | CONCLUSIONS}

We acknowledge that cinema and education projects exhibit and work technically with films that students would not have the opportunity to watch at any other time or place. On their turn, young students stated having enjoyed cinema classes and that they feel happy for taking part in these projects. In general, they say that since they began participating in the cinema workshops, they have watched films more attentively and with different eyes.

This theoretical model will be a combined construct coming from successful approaches and projects of social inclusion by film education, and scaling up and transferring it to different contexts. Film education can be a strong mediator to facilitate transformative learning. It can change one's dysfunctional views and beliefs about oneself and the world, by revising their frames of reference (Taylor, 2009). Films have a unique ability to promote empathy towards a role model, and promote resilience in situations similar to those the role model goes through (González Blasco \& Moreto, 2012; Heynes \& Tanner, 2013; Morin, 1997). Furthermore, media, such as films, is capable of reaching people that might otherwise be uninterested (Buckingham, 2007; Gonnet, 2007; Silverstone, 2005; UNESCO, 2013).

To help these target group to successfully promote the social inclusion of disadvantaged children, this project promoted individual and cultural competences, i.e., one's ability to be able to understand and respect the uniqueness of each individual; that is, to treat each person as an individual and not just see them as some sort of stereotype of a certain group they belong to.

\section{REFERENCES}

Ascenso, J. (2012). Os caminhos da felicidade. O Globo, $17 \quad$ nov. 2012. http://oglobo.globo.com/saude/os-caminhos-dafelicidade-6758750.

Bergala, A. (2008). A hipótese cinema: pequeno tratado de transmissão do cinema. Rio de Janeiro: Booklink.

Buckingham, D. (2007). The making of citizens: young people, news and politics. Londres: Routledge.

Chaves, G. M. (2010). Para além do cinema: o cineclubismo de Belo Horizonte (1947-1964). Masters Dissertation, Universidade Federal de Minas Gerais, Belo Horizonte.

Clarembeaux, M. (2010). Educación en cine: memoria y patrimonio. Revista Comunicar, 35, pp. 25-32;XVIII. Huelva: Grupo Comunicar.

Duarte, R. (2009). Cinema e Educação. Belo Horizonte: Autêntica Editora.

Duarte, R. (2012). A educação como estratégia de preservação do cinema. Paper presented at the 7th Cine OP, June/2012. www.cinemasemfronteiras.com.

Fantin, M. (2005). Mídia-educação: conceitos, experiencias, diálogos Brasil-Itália. Florianópolis: Editora Cidade Futura.

Fantin, M. (2011). Mídia-educação: aspectos históricos e teórico-metodológicos. Olhar de Professor, 1(1).

Freire, P. (2005). Pedagogia do oprimido. São Paulo: Paz e Terra.

Gonnet, J. (2007). Educação para os media:as controvérsias fecundas. Porto: Porto Editora.

Kaplún, M. (2002). Una pedagogía de la comunicación (el comunicador popular). La Habana: Editorial Caminos.

Livingstone, S., Haddon, L., Görzig, A., \& Ólafsson, K. (2010). Risks and safety on the internet: The 
perspective of European children: full findings. Londres: EU Kids Online, LSE.

Morin, E. (1978). Le cinéma ou l'homme imaginaire. Paris: Les Éditions de Minuit.

Morin, E. (2000). Les sept savoirs nécessaires à l'éducation du futur. Paris: Le Seuil.

Neves, P. J.F. B. (2011). O cinema na escola. Estudo de caso - a disciplina de opção cinema no $3^{\circ}$ ciclo, no Algarve. Percurso e efeitos no tempo. Masters dissertation. FCHS - Universidade do Algarve.

Pereira, A. C. (2011). O cinema ao serviço da educação: A experiência das escolas de ensino básico e secundário no Algarve. Revista Comunicação \& Educação, n. 1; XVI.

Mezirow, J. \& Taylor, E. W. (2009). Transformative learning in practice: insights from community, workplace, and higher education.San Francisco: Jossey Bass.

Pacheco, R. (2016). Cinema e Educação. Estudos de Caso no Brasil e em Portugal. Tese de Doutoramento em Ciências da Comunicação, Universidade Nova de Lisboa.

Pinto, M. (2014). "O trabalho em rede na definição de uma política de literacia mediática”, in I. Eleá (ed.). Agentes e vozes: um panorama da mídia-educação no Brasil, Portugal e Espanha. Sweden: Nordicom, pp. 157-164.

Ponte, C. (2012). Crianças e Media. Pesquisa internacional e contexto português do século XIX à actualidade. Lisboa: ICS.

Rancière, J. (2010). O espectador emancipado. Lisboa: Orfeu Negro.

Reia-Baptista, V. (2010). Presentación: Lenguajes fílmicos en la memoria colectiva de Europa. Revista Comunicar, 35, pp. 10-13;XVIII.

Reia-Baptista, V. et al. (2014). Screening Literacy: Reflecting on Models of Film Education in Europe. Revista Latina de Comunicación Social, 69, pp. 354365.

http://www.revistalatinacs.org/069/paper/1015_UK/1 8ven.html.

Scocuglia, A. C. (1999). A história de Paulo Freire e a atual crise de paradigmas. João Pessoa: Editora Universitária.
Silverstone, R. (2005). Why study the media? London: Sage Publications.

Sodré, M. (2012). Reinventando a educação: diversidade, descolonização e redes. Petrópolis: Vozes.

Xavier, I. (1978). Sétima arte: um culto moderno. O idealismo estético e o cinema. São Paulo: Editora Perspectiva.

UNESCO (2013). Expertos de la UNESCO destacan la alfabetización mediática e informacional como competência clave para el siglo XXI. Gabinete Comunicación y Educación, Barcelona. http://www.gabinetecomunicacionyeducacion.com/e s/noticias/expertos-de-la-unesco-destacan-laalfabetizacion-mediatica-e-informacional-comocompetencia. 
CITAR Journal, Volume 11, No. 1 - Thematic Dossier: Marginalized Narratives 